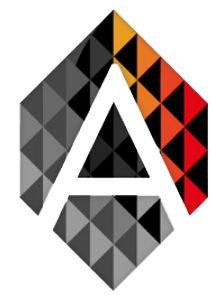

\title{
Elements for the Agent-Based Modeling of Slavery Systems
}

\author{
Antônio Carlos da Rocha Costa ${ }^{a}$ \\ a Programa de Pós-Graduação em Filosofia, Pontifícia Universidade Católida do Rio Grande \\ do Sul - PUCRS, Av. Ipiranga, 6681. CEP 90619-900 Porto Alegre, RS, Brazil. \\ ac.rocha.costa@gmail.com
}

\begin{tabular}{|c|c|}
\hline RD & ABSTRACT \\
\hline $\begin{array}{l}\text { Agent-basec; } \\
\text { Modeling; } \\
\text { Slavery-based } \\
\text { economic } \\
\text { systems; Agent } \\
\text { societies }\end{array}$ & $\begin{array}{l}\text { This paper introduces formal concepts for the agent-based modeling of slavery } \\
\text { systems. The concepts of master-slave economic relationship, slavery-based } \\
\text { economic system, slavery-supporting legal system, and slavery-based material } \\
\text { agent society are formally defined. A first case study recasts, for material } \\
\text { agent societies, North \& Thomas' economic model determining the objective } \\
\text { conditions under which it is rational for a society to choose a slavery-based } \\
\text { economic system over a free labor-based economic system. A second case study } \\
\text { makes use of elements of } F \text {. H. Cardoso's study of slavery in the south of Brazil } \\
\text { to illustrate the application of the formal concepts introduced in the paper. }\end{array}$ \\
\hline
\end{tabular}

\section{Introduction}

In this paper, we introduce a conceptual framework supporting the agent-based modeling of general slavery systems (see, e.g., (Archer, 1988) for a general account of the history and varieties of slavery). Material agent societies and their elementary economic systems (Costa, 2018) are taken as the formal societal context in which general slavery systems are modeled.

The social and economic master-slave relationships that characterize slavery systems, the economic systems that arise from them, and the legal systems that support them, are informally explained and formally defined. A formal general definition is given of slavery-based material agent societies.

So called chattel slavery is assumed as the basic form of slavery, and is formally characterized. A case study recasts North \& Thomas' economic model determining the objectives conditions under which it is rational for a society to choose a slavery-based economic system over a free labor-based economic system.

The aim of the present paper, in line with the work that has been done concerning agent societies in general (Costa, 2017c; Costa, 2019), and material agent societies in particular (Costa, 2017b; Costa,

Antônio Carlos da Rocha Costa Elements for the Agent-Based Modeling of Slavery Systems
ADCAIJ: Advances in Distributed Computing and Artificial Intelligence Journal Regular Issue, Vol. 9 N. 1 (2020), 15-27 eISSN: 2255-2863 - https://adcaij.usal.es Ediciones Universidad de Salamanca - CC BY-NC-ND 
2018), is to provide an agent-based semantical model for formal social and political theories of slavery-based societies.

However, we investigate no single theory of slavery-based societies, regarding such applicability. In particular, we do not go beyond the general level of detail of the concepts mentioned above.

\section{Agent Societies}

A detailed formal account of the architecture of material agent societies that are organized on the basis of slavery is out of the scope of the present paper. Here, we can only leave implicit the amount of details that would have to be provided in order to properly instantiate, as a slavery-based material agent society.

We take the following as the general structure of an agent society (Costa, 2017c):

- $A g S o c=(P o p, O r g, M E n v$, SEnv, IMP, ACC $)$

where:

- Pop is the population of AgSoc;

- Org is the organizational structure of AgSoc;

- MEnv is the material environment of AgSoc;

- SEnv is the symbolic environment of AgSoc, where the society's system of legal norms is embedded;

- IMP is the collection of implementation relations between Pop and Org;

- ACC is the collection of access relations of Pop and Org to the environments MEnv and SEnv.

Moreover, considering the case of slavery-based material agent societies that do not produce slaves by capturing them in another society, but that, besides producing them by parental reproduction, also import them from slave capturing societies, the full account of the details of that slavery-based society would require placing it in an inter-societal context (see (Costa, 2017a)), which is also out of the scope of the present paper.

\section{Elementary Economic Exchanges in Material Agent Societies}

As in (Costa, 2017b) and (Costa, 2018), we say that an agent is a material agent whenever that agent has a material body, that is, a body that requires energy for its operation. And we call material agent society any agent society whose agents are all material agents.

We call energy producer any material agent that is capable of producing energy objects, with which energy is distributed for consumption in the society. All the other material agents of that society are said to be energy consumers.

Formally, we denote:

- EnergProd: the set of material agents that are energy producers;

- EnergCons: the set of material agents that are energy consumers.

Antônio Carlos da Rocha Costa Elements for the Agent-Based Modeling of Slavery Systems
ADCAIJ: Advances in Distributed Computing and Artificial Intelligence Journal Regular Issue, Vol. 9 N. 1 (2020), 15-27 eISSN: 2255-2863 - https://adcaij.usal.es Ediciones Universidad de Salamanca - CC BY-NC-ND 
Two types of objects are assumed to be exchangeable in an elementary economic exchange between two material agents:

- EnergObj, the type of the so-called energy objects, that is, objects that are carriers of the energy needed by the material agents for their functioning;

- Chip, the type of the so-called chips, that is, valuable objects that the material agents may be interested to acquire, possibly by exchanging some of the energy objects they have in their possession;

so that, in general, an elementary economic exchange is constituted by an exchange between two material agents where:

- either one or more energy objects are exchanged for one or more chips;

- or one or more chips of a given subtype are exchanged for one or more chips of another subtype. We will be mainly interested in elementary economic exchanges of the first kind.

\section{Slavery-Based Economic Systems}

\subsection{Masters and Slaves in Chattel Slavery}

Chattel slavery is slavery where slaves are considered personal belongings of their masters, which can dispose of them as they wish. Other forms of slavery also exist (see, e.g., (Archer, 1988)).

In this paper, we take into account only chattel slavery. However, we make an informal use of the term property, that is, we use property to mean both informal, non-legally supported ownership of objects, as well as formal, legally supported ownership of objects, slaves being a particular type of ownable objects (Blackburn, 1988, p.276):

«the slave status and condition has been a purely social construction - that of a social isolate, an outsider, a person without kin, a person subject to the complete and arbitrary authority of the master, a person who could be whipped or tortured or sexually abused, a piece of property, and, by virtue of the foregoing, an instrument. The very enumeration of such qualities must remind us that slavery was not a suprahistorical essence but had to be produced and perpetuated, enlisting the support of the free population and adapting the slave to the particular use required.»

Given a material agent society MatAgSoc, we formally define ${ }^{1}$

- MatObj: the set of material objects of MatAgSoc;

- MatAg $\in \wp($ MatObj): the set of material agents of MatAgSoc;

- Master $\in \wp($ MatAg): the set of masters of MatAgSoc;

- Slave $\in \wp(M a t A g)$ : the set of slaves of MatAgSoc. For simplicity, we take that:

- Master $\cap$ Slave $=\varnothing$ : no master is a slave, and vice-versa;

- Master $\in \wp($ EnergCons $):$ all masters are energy consumers;

- Slave $\in \wp($ EnergProd): all slaves are energy producers.

$1 \wp(X)$ is the powerset of set $X$.

Antônio Carlos da Rocha Costa Elements for the Agent-Based Modeling of Slavery Systems
ADCAIJ: Advances in Distributed Computing and Artificial Intelligence Journal Regular Issue, Vol. 9 N. 1 (2020), 15-27 eISSN: 2255-2863 - https://adcaij.usal.es Ediciones Universidad de Salamanca - CC BY-NC-ND 
In the following sections, we introduce formal accounts of diverse aspects of the property relationship between masters and slaves.

\subsection{Master-Slave Property Relationship}

We call master-slave property relationship the system of actions, norms and commands that empower the set of masters of a slave-based material agent society, so that they can maintain slaves in their slavery condition.

Formally, we characterize the property relationship between masters and slaves in the following way:

- owns $\subseteq$ Master $\times$ Slave, the property relation between masters and slaves, so that owns $\left(\right.$ master $_{i}$, slave $_{j}$ ) means that master master $_{i}$ owns slave .

The property relationship allows master and master $_{k}$ to do any of the following actions on slave, whenever it happens that owns(master ${ }_{i}$, slave ): $_{j}$

- sell (master, slave $_{j}$, master $_{k}$ )

- lend ( master $_{i}$, slave $_{j}$, master $\left._{k}\right)$

- $\operatorname{rent}\left(\right.$ master, $_{i}$, slave ${ }_{j}$, master $\left._{k}\right)$

- kill ( master $_{i}$, slave $\left._{j}\right)$

- free (master $_{i}$, slave $\left._{j}\right)$

- command (master, slave $_{j}, \mathrm{cmd}$ )

- punish(master ${ }_{i}$ slave $_{j}$, cmd)

meaning that:

- master $_{i}$ can sell, lend and rent slave ${ }_{j}$ to any other master master $_{k}$, besides killing or freeing it, and commanding it to perform any command $\mathrm{cmd}$, as well as punishing it for the way it performed such command.

In accordance with the possibility of master ${ }_{i}$ performing sell (master ${ }_{i}$, slave, master $_{k}$ ), we take that master $_{k}$ can buy slave slave $_{j}$ from master master $_{i}$. That is, we also have, as possible action:

- buy (master ${ }_{k}$, slave $_{j}$, master $\left._{i}\right)$

Additionally, the following (formal or informal) obligation is taken to be valid for slaves:

- mustexec(slave $e_{j}$ cmd, master ${ }_{i}$ ) meaning that:

- slave $_{j}$ is supposed to peremptorily execute any command $\mathrm{cmd}$ issued by master $_{i}$.

For simplicity, we omit here any reference to the conditions under which those actions and commands may be effective, such as the explicit connection between commands and possible punishments. But, see Section 5 for some of the legal types of such conditions.

Other legal forms of acquisition of slaves (such as by having them born from parents that are already slaves, or by capturing them in certain specified conditions) are also considered in Section 5 .

Antônio Carlos da Rocha Costa Elements for the Agent-Based Modeling of Slavery Systems
ADCAIJ: Advances in Distributed Computing and Artificial Intelligence Journal Regular Issue, Vol. 9 N. 1 (2020), 15-27 eISSN: 2255-2863 - https://adcaij.usal.es Ediciones Universidad de Salamanca - CC BY-NC-ND 


\subsection{Master-Slave Economic Exchanges}

Let time be given by the linearly ordered set $T=\{0,1,2, \ldots\}$, ranged over by variable $t$. For the purpose of the present paper, we call elementary economic exchange any exchange of the form (cf. (Costa, 2018)):

$$
e^{2 e x c h}{ }^{t}=\langle m a g / o b j\rangle^{t} c^{\prime \rightleftarrows}{ }^{c}\left\langle m a g^{\prime} / o b j^{\prime}\right\rangle^{t}
$$

meaning that material agents $m a g$ and $m a g^{\prime}$ exchange objects $o b j$ and $o b j$, a pair of such objects at each time $t$, under the assumption that mag provides operational condition $c$ for $\mathrm{mag}^{\prime}$ to produce and delivery $o b j$ ', and $m a g^{\prime}$ provides operational condition $c^{\prime}$ for $m a g$ to produce and delivery $o b j$.

We call master-slave elementary economic exchange any elementary economic exchange of the form:

$$
\text { mse2exch }{ }^{t}=\langle\text { master } / \perp\rangle^{t} \rightleftarrows^{c}\langle\text { slave } / o b j\rangle^{t}
$$

meaning that, at each $t$, slave sends an object obj to his master master, without receiving no object in exchange ( $\perp$ is the null object), while the master master is required to provide condition $c$ for slave to produce and delivery $o b j$, and the slave slave is not required to provide any condition $(\perp)$ for the master to produce and delivery nothing $(\perp)$.

Notice that in any master-slave elementary economic exchange like $m s e 2 e x c h$, masters accumulate a set of received objects, up to time $t$, in the form:

$$
\text { accumobj }\left[\text { master } / \text { mseQproc }{ }^{t}\right]=\left\{o b j^{0}, o b j^{1}, \ldots, o b j^{t}\right\}
$$

while slaves accumulate nothing, because we take that a set of null objects is an empty set. That is:

$$
\text { accumobj[slave/mse2proc } \left.{ }^{t}\right]=\left\{\perp^{0}, \perp^{1}, \ldots, \perp^{t}\right\}=\emptyset
$$

In general, masters are allowed to have a group of slaves with more than one slave in it. In such a case, the master-slave group elementary economic exchange that the master and the group of slaves perform has the form:

$$
\text { msge2exch }{ }^{t}=\langle\text { master } / \perp\rangle^{t} \rightleftarrows^{c}\langle\text { Slave } / O b j\rangle^{t}
$$

where:

- Slave is the group of slaves that belong to master;

- Obj is the set of objects that the set of slaves Slave produce and deliver, at each time, to master.

\subsection{Slavery-Based Elementary Economic Processes}

In general, individual elementary economic processes have the form (see (Costa, 2018)):

$$
\begin{aligned}
i e 2 \operatorname{proc}^{t}=\left\langle\mathrm{mag}_{1} / \perp, o b j_{1,2}\right\rangle^{t}{ }_{c_{2,1}} \rightleftarrows^{c_{1,2}}\left\langle\mathrm{mag}_{2} / o b j_{2,1}, o b j_{2,3}\right\rangle^{t}{ }_{c_{3,2} \rightleftarrows c_{2,3}} \ldots \\
\cdots c_{n, n-1} \rightleftarrows c_{n-1, n}\left\langle m a g_{n} / o b j_{n, n-1}, \perp\right\rangle^{t}
\end{aligned}
$$

Antônio Carlos da Rocha Costa Elements for the Agent-Based Modeling of Slavery Systems
ADCAIJ: Advances in Distributed Computing and Artificial Intelligence Journal Regular Issue, Vol. 9 N. 1 (2020), 15-27 eISSN: 2255-2863 - https://adcaij.usal.es Ediciones Universidad de Salamanca - CC BY-NC-ND 
where:

- $m a g_{i}$ is the $i$-th material agent participating in $i e 2$ proc $^{t}$;

- each $\left\langle m a g_{i} / o b j_{i, i-1}, o b j_{i, i+1}\right\rangle^{t} c_{i+1, i} \rightleftarrows c_{i, i+1}\left\langle m a g_{i+1} / o b j_{i+1, i}, o b j_{i+1, i+2}\right\rangle^{t}$ is an elementary economic exchange;

- $o b j_{i}{ }^{\prime} k$ is the object that $\operatorname{mag}_{i}$ produces and deliveries to its $k$-th partner, for $k \in\{i-1, i+1\}$;

- $\mathrm{mag}_{1}$ has no left partner, so $o b j_{1,0}=\perp$;

- $m a g_{n}$ has no right partner, so $o b j_{n, n+1}=\perp$.

In the general case of slavery-based elementary economic processes, we have the form:

$$
\begin{aligned}
& \text { mse2proc }^{t}=\left\langle\text { master }_{1} / \perp, o b j_{1,2}\right\rangle^{t} c_{2,1} \rightleftarrows^{c_{1,2}}\left\langle\text { master }_{2} / o b j_{2,1}, o b j_{2,3}\right\rangle_{c_{3,2}} \rightleftarrows^{c_{2,3}} \ldots \\
& \cdots c_{n, n-1} \rightleftarrows c_{n-1, n}\left\langle\text { master }_{n} / o b j_{n, n-1}, \perp\right\rangle^{t}
\end{aligned}
$$

where one can notice that only masters participate in the society's economic processes, slaves being restricted to private economic exchanges with their masters, as sketched in Figure 1. Notice that a master participates in two elementary economic exchanges (one local, with his slave, the other global, with other masters), while a slave participates only in one elementary economic exchange, the local exchange with its master.

Notice also that this model of slavery-based elementary economic processes naturally extends to the cases where the masters may have groups of slaves, instead of just individual slaves.

\subsection{Slavery-Based Elementary Economic Systems}

Let the term elementary economic material agent denote a material agent of the population of a material agent society that can participate in an elementary economic exchange. We define the general notion of elementary economic system of a material agent society as follows (cf. (Costa, 2018)):

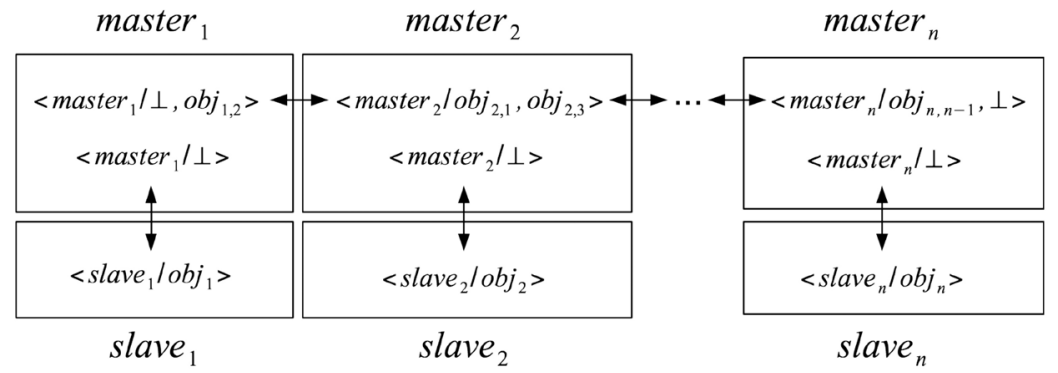

Figure 1: Sketch of a slavery-based elementary economic process.

Definition 4.1 The elementary economic system E2Sys of a material agent society MAgSoc is a time-indexed structure:

$$
E_{2 S y s_{M A g S o c}^{\mathrm{t}}}=\left(E 2 M A g^{\mathrm{t}}, \text { Objs }^{\mathrm{t}}, E 2 \text { Beh }^{\mathrm{t}}, E^{2} E_{x c h}^{\mathrm{t}}, E^{2} \operatorname{Proc}^{\mathrm{t}}\right)
$$

Antônio Carlos da Rocha Costa Elements for the Agent-Based Modeling of Slavery Systems
ADCAIJ: Advances in Distributed Computing and Artificial Intelligence Journal Regular Issue, Vol. 9 N. 1 (2020), 15-27 eISSN: 2255-2863 - https://adcaij.usal.es Ediciones Universidad de Salamanca - CC BY-NC-ND 
where, for each time t:

- E2MAg ${ }^{t}$ is the set of elementary economic material agents, which participate in the elementary economic processes of MAgSoc, at the time $t$;

- Objs ${ }^{t}$ is the set of objects that the elementary economic agents can exchange during the performance of their elementary economic exchanges, at that time;

- E2Beht is the set of elementary economic behaviors that the elementary economic material agents can perform during the performance of the elementary economic exchanges, at that time;

- E2Exch ${ }^{t}$ is the set of elementary economic exchanges that the elementary economic material agents can perform during the performance of the elementary economic processes, at that time;

- E2Proc ${ }^{t}$ is the set of elementary economic processes that the elementary economic material agents can perform in MAgSoc, at that time.

In the case of a slavery-based elementary economic system, we have that, for any time $t$ :

- E2MAg ${ }^{t}=$ Master $^{t} \cup$ Slave $^{t}$, meaning that the set of elementary economic material agents of E2Sys ${ }^{t}$ is partitioned into masters and slaves;

- $\mathrm{Obj}^{t}=$ MasterSlaveObj $\cup$ MasterMasterObjt, meaning that the objects exchanged between elementary economic agents are either of the master-slave type or of the master-master type, with (see (Costa, 2018)):

- MasterSlaveObj ${ }^{t} \in \wp($ EnergObj $)$, that is, objects exchanged between masters and slaves (in fact, just from slaves to masters) are energy objects, resulting from the labor of the slaves;

- MasterMasterObjt $\in \wp(E n e r g O b j) \cup \wp(C h i p)$, that is, objects exchanged between masters are either energy objects or chips, with chips exchanged in return for energy objects;

- E2Beh = MasterE2Beh $\cup$ SlaveE2Beht, that is, both masters' and slaves' elementary economic behaviors may participate in the elementary economic exchanges of E2Sys ${ }_{\text {MAgSoc }}^{t}$;

- E2Exch = MasterSlaveE2Exch ${ }^{t} \cup$ MasterMasterE2rExch ${ }^{t}$, that is, the elementary economic exchanges are either of the master-slave type or of the master-master type;

- E2Proc = MasterSlaveE2Proc ${ }^{t} \cup$ MasterMasterE2Proc ${ }^{t}$, that is, the elementary economic processes are either of the master-slave type or of the master-master type.

Notice that no particular requirement is established concerning the types of conditions that may be imposed on the elementary economic exchanges.

\section{Slavery-Supporting Legal Systems}

\subsection{Legal Systems of Agent Societies}

We define the general notion of legal system situated in a general agent society $\mathrm{AgSoc}$ as follows (cf. (Costa, 2015)):

Definition 5.1 A legal system situated in AgSoc is a time-indexed structure:

$$
\text { LegalSys }_{\text {AgSoc }}^{t}=\left(\text { LOrd }^{t}, \text { LOrg }^{t}, \text { RLFact }^{t}, \text { LegalOps }\right)
$$

Antônio Carlos da Rocha Costa Elements for the Agent-Based Modeling of Slavery Systems
ADCAIJ: Advances in Distributed Computing and Artificial Intelligence Journal Regular Issue, Vol. 9 N. 1 (2020), 15-27 eISSN: 2255-2863 - https://adcaij.usal.es Ediciones Universidad de Salamanca - CC BY-NC-ND 
where:

- LOrd is the legal order at time t;

- $\operatorname{LOrg}^{t}$ is the system of legal organs at time t;

- RLFact ${ }^{t}$ is the record of legal facts at time $t$;

- LegalOps is the set of legal operations, like:

- createlnrm, the creation of legal norms;

- deroglnrm, the derogation of legal norms;

- createlauth, the creation of authorizations to perform legal operations;

- cancellauth, the cancellation of such authorizations;

- recordlfct, the recording of a legal fact in RLFact;

- deletelfct, the deletion of one such record.

with:

- RLFact freely accessible to all the agents of the society;

- $\operatorname{LOrd}^{t}$ and $\mathrm{LOrg}^{t}$ such that $\mathrm{LOrd}^{0} \neq \varnothing \neq \operatorname{LOrg}^{0}$.

\subsection{Legal Systems in Slavery-Based Material Agent Societies}

In the context of slavery-based material agent societies endowed with legal systems, we are particularly interested in the types of legal norms that support the masters in their maintenance of the slave-based economic relationship.

Cleraly, the most fundamental of such legal norms are:

- owns(master ${ }_{i}$ slave $) \Rightarrow$ Auth (master ${ }_{i}$, command (master $_{i}$, slave $_{j}$, cmd), which legally authorizes master master ${ }_{i}$ to command that slave slave ${ }_{j}$ does any command the master wishes;

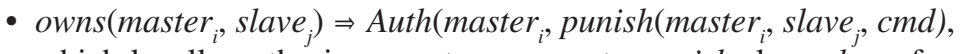
which legally authorizes master master ${ }_{i}$ to punish slave slave $_{j}$ for not doing properly any command that the master has commanded it to do.

Typically, the following conditional legal authorization is also formally adopted by the legal systems of slave-based material agent societies, so that the initial condition for a material agent to become a slave, and for which is to be its initial master, is established:

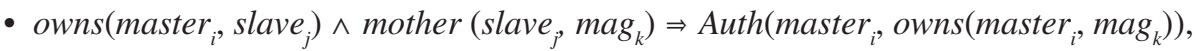
which legally authorizes master master ${ }_{i}$ to own the material agent mag $_{k}$ as a slave, if the mother of $\mathrm{mag}_{k}$ is itself owned as a slave by master master ${ }_{i}$.

Legal norms as the above ones, are sufficient for material agent societies whose only means to produce slaves is through their parental reproduction. Some material agent societies, however, adopt the legal procedure of allowing slaves to be produced by their capturing from other societies (either in the context of war between the two societies, or in the context of a commercial exploitation of the second society by the first one). That type of legal norm may be formally sketched as follows:

- autorized $\left(\right.$ mag $_{i}$, slavecapture $) \wedge$ captured $\left(\operatorname{mag}_{i}, \operatorname{mag}_{j}\right) \Rightarrow \operatorname{Auth}\left(\operatorname{mag}_{i}\right.$, owns $\left._{\left(\text {mag }_{i}, \operatorname{mag}_{j}\right)}\right)$,

Antônio Carlos da Rocha Costa Elements for the Agent-Based Modeling of Slavery Systems
ADCAIJ: Advances in Distributed Computing and Artificial Intelligence Journal Regular Issue, Vol. 9 N. 1 (2020), 15-27 eISSN: 2255-2863 - https://adcaij.usal.es Ediciones Universidad de Salamanca - CC BY-NC-ND 
which states that if material agent $\mathrm{mag}_{i}$ is legally authorized to capture slaves, and it happened that $m a g_{i}$ captured $m a g_{j}$ then $m a g_{i}$ is legally authorized to own $m a g_{j}$ as a slave, effectively making of mag $_{i}$ a master and of $m a g_{j}$ a slave.

\section{A First Case Study: North \& Thomas' Economic Model of Ra- tional Choice between Slavery and Free Work in Material Agent Societies}

\subsection{Presentation}

Douglass C. North and Robert Paul Thomas develop in (North and Thomas, 1971) an institutional dynamical model for the rise and fall of manorial systems, that encompasses both serfdom and slavery. They contrast serfdom an slavery by telling the former system to be «essentially a contractual arrangement where labor services were exchanged for the public good of protection and justice» (p.778), with a «contractual relationship which could be changed only by both parties» (p.779), while in the latter system a slave «has no legal control over decision-making with respect either to his labor or to his income stream» (p.779).

Clearly, by basing the distinction on the notion of contract, North \& Thomas' model presupposes the existence of some sort of (formal or informal) legal system that is effective in the society and capable of enforcing the compliance with valid contracts.

The core of their rational model for the choice between slavery-based and free labor-based economic system is the following:

«Slavery was always more profitable than free labor <..> when the following conditions existed: (1) a market economy, (2) profitable opportunities to produce those types of economic activities where the costs of supervision to reduce shirking were low, and (3) where the costs of enforcing property rights in human beings were low.» (p.779)

Notice that:

1. Condition (1) encompasses the possibility of freely selling and buying slaves.

2. Let costsuperv(master ${ }_{i}$, slave ${ }_{j}$ ) denote the cost of the supervision, for master master ${ }_{i}$, of the operation of the slave slave. Analogously, denote the cost of the corresponding supervision, concerning the free laborer freelaborer $k$, by costsuperv ( master $_{i}$, freelaborer ${ }_{k}$ ). Then, condition (2) means that it is rational for the society to choose a slavery-based economic system over a free labor-based economic system if and only if, for a typical master (mstr), it holds that:

$$
\sum_{j=1}^{j=n} \operatorname{costsuperv}\left(\text { mstr }_{,} \text {slave }_{j}\right) \leq \sum_{k=1}^{k=m} \operatorname{costsuperv}\left(\text { mstr }, \text { freelaborer }_{k}\right)
$$

where:

- $n$ is the average number of slaves owned by mstr, in the alternative of the slavery-based economic system;

- $m$ is the average number of free laborers hired by $m s t r$, in the alternative of the free labor-based economic system.

Antônio Carlos da Rocha Costa Elements for the Agent-Based Modeling of Slavery Systems
ADCAIJ: Advances in Distributed Computing and Artificial Intelligence Journal Regular Issue, Vol. 9 N. 1 (2020), 15-27 eISSN: 2255-2863 - https://adcaij.usal.es Ediciones Universidad de Salamanca - CC BY-NC-ND 
3. Let costenforc( master $_{i}$, slave ${ }_{j}$ ) denote the cost, for master master ${ }_{i}$, of enforcing property rights on the slave slave (both regarding the slave itself and the other competing masters). Analogously, let costenforc (master ${ }_{i}$, freelaborer ${ }_{k}$ ) denote the cost, for master master ${ }_{i}$, of the corresponding enforcement, concerning the labor of the free laborer freelaborer ${ }_{k}$. Then, condition (3) means that it is rational for a society to adopt a slavery-based economic system over a free labor-based economic system if and only if, for a typical master (mstr), it holds that:

$$
\sum_{j=1}^{j=n} \operatorname{costenforc}\left(\text { mstr } \text { slave }_{j}\right) \leq \sum_{k=1}^{k=m} \operatorname{costenforc}\left(\text { mstr }, \text { freelaborer }_{k}\right)
$$

where:

- $n$ is the average number of slaves owned by mstr, in the alternative of the slavery-based economic system;

- $m$ is the average number of free laborers hired by $m s t r$, in the alternative of the free labor-based economic system.

In summary, one can see, by this brief account of the elements of North \& Thomas' model, that a rational choice is possible between a slavery-based economic system and a free labor-based economic system, in any given material agent society, at any time of its history.

\subsection{Discussion}

The basic elements of North and Thomas' (North and Thomas, 1971) model for the rational choice between slavery-based and free labor-based economic systems was briefly reviewed. One sees that the analysis of their model opens the possibility for a mixed type of economic systems of material agent societies, namely, that which combines slave material agents and free laborer material agents.

Two criteria arise for a rational choice between slavery and free laboring, in such mixed situations:

- first, a choice at the level of the type of economic activity: choose between slavery and free laboring according to the costs of work supervision and property rights enforcement peculiar to each activity;

- second, a choice at the level of the particular situation of the master: choose between slavery and free laboring according to the costs of work supervision and property rights enforcement for each particular master.

A situation where the full combination of all such possibilities are adopted would certainly introduce extra complexity in the legal system of the society, because legal provisions would have to be established for each such possibility, including different legal norms applying to the same master, in accordance with the particular type of economic relation he has with each of his workers.

A more sensible choice would be that the material agent society chooses, for each type of economic activity, either slavery or free labor. In such case, the legal norms of the legal system, concerning the way work is performed in the material agent society, could be specialized for the different types of economic activities.

Antônio Carlos da Rocha Costa Elements for the Agent-Based Modeling of Slavery Systems
ADCAIJ: Advances in Distributed Computing and Artificial Intelligence Journal Regular Issue, Vol. 9 N. 1 (2020), 15-27 eISSN: 2255-2863 - https://adcaij.usal.es Ediciones Universidad de Salamanca - CC BY-NC-ND 
Finally, notice that even if the legal system of the society adopts only free labor based economic activities, it may be rational for some particular economic activity, or for some particular master, to establish slavery-based forms of economic exchange with its workers, giving rise to illegal slavery forms of economic activities in the society.

\section{A Second Case Study: The Economic Fall of Slavery in Colonial South Brazil}

\subsection{The Colonial Situation}

The colonial condition of Brazil, under Portuguese rule, is considered to have began with the first arrival of the Portuguese navigators in the land, in 1500, and to have ended with the national independence, in 1822 (see, e.g., (Klein and Luna, 2010), see also (Wikipedia, 2019)).

From the XVI century, the economy of the northeast region of Brazil was based on slavery-based sugar plantations, operating as sugar exporters for the metropole in Lisbon, during the colonial period, and to Europe in general, after the independence.

From the end of the XVIII century up to the legal abolition of slavery, in 1888, the economy of the southern region of Brazil was based on slavery-based charque factories, called charqueadas, which exported charque (beef jerky) mainly for those northeastern plantations, to serve as slave food. By the end of the XIX century, that economy reached its exhaustion, and failed to continue profitable even before the legal abolition of slavery.

In the next subsection, we formally analyze, if in a very sketchy way, the fall of the slavery-based economic system of the southern region of colonial Brazil.

\subsection{A Formal Account of the Fall of the Slavery-Based Economic System of Southern Colonial Brazil}

This section builds on elements of the classical socio-political-economic study of the slavery-based economy of southern colonial Brazil, by F. H. Cardoso (Cardoso, 1997). Figure 2 shows the main economic and political actors operating in that system. The northeastern Brazilian plantations were the consumers of the charque produced by the southern Brazilian charque producers. We denote their economic exchanges (arrow A in Fig. 2) simply by:

$$
\text { BCharPlantExch }{ }^{t}=\langle\text { BChar } / \text { charque }\rangle^{t} \rightleftarrows\langle\text { Plant } / \text { money }\rangle^{t}
$$

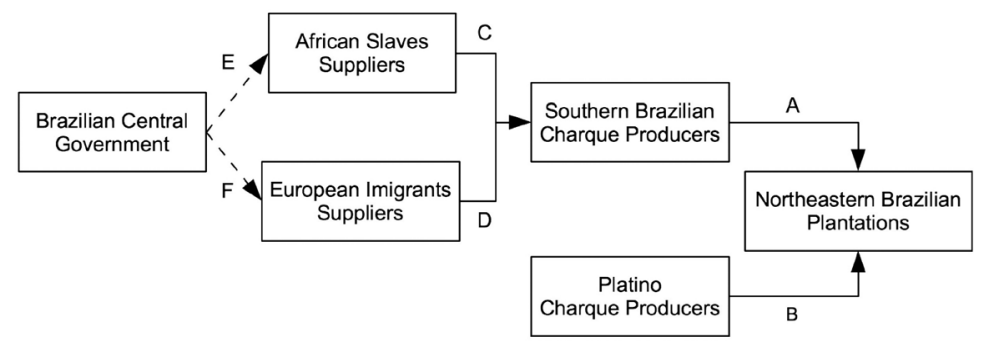

Figure 2: Sketch of the situation of the southern Brazilian charque producers.

Antônio Carlos da Rocha Costa Elements for the Agent-Based Modeling of Slavery Systems
ADCAIJ: Advances in Distributed Computing and Artificial Intelligence Journal Regular Issue, Vol. 9 N. 1 (2020), 15-27 eISSN: 2255-2863 - https://adcaij.usal.es Ediciones Universidad de Salamanca - CC BY-NC-ND 
The Platino charque producers were charque producers located in the neighbor countries of Uruguay and Argentina, on the shores of the Plata river. In opposition to the Brazilian producers, they operated with free labor-based industries, and consequently were strong competitors of the Brazilian producers. We denote their economic exchanges (B) with the northeastern Brazilian plantations by:

$$
\text { PCharPlantExch }{ }^{t}=\langle\text { PChar } / \text { charque }\rangle^{t} \rightleftarrows\langle\text { Plant } / \text { money }\rangle^{t}
$$

African slave suppliers arrived in Brazil as early as the XVI century. They flourished until the middle of the XIX century, when slave traffic was legally forbidden. Their exchanges with the charque producers is denoted by:

$$
\text { SSuppPCharExch }{ }^{t}=\langle\text { SSupp } / \text { slaves }\rangle^{t} \rightleftarrows\langle\text { PChar } / \text { money }\rangle^{t}
$$

The continuous supply of slaves for the charque producers was a crucial issue in their business, since a continuous renovation of slaves was required, given that slaves were useful as workers for relatively short time, due to the hard conditions of their jobs. Additionally, the increase of the number of slaves was the only way to increase the amount of charque production, when the demand for that product increased, due to the low level of technology of that industry.

For most of the time the charque industry was in operation, the the adoption of a slave-based organization of the production was a rational choice, that is, for the typical Brazilian charque producer it used to hold that:

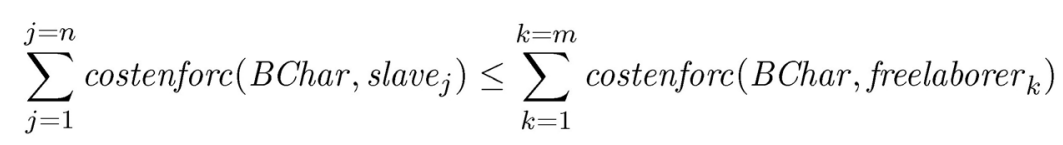

That changed, however, when the legal supply of slaves finished and the black market of slave supplies soon became risky and overpriced. The adoption of a free labor-based organization of their charqueadas immediately presented itself. But, since the slavery system was so generalized in Brazil, no stimulus had occurred in its history for the formation of free laborers for any of the main economic sectors of the county.

The alternative for most of those sectors (specially for the coffee plantations) was the importation of foreign workers, mainly from Europe, which was increasingly being stimulated by the Brazilian central government.

That was no applicable to the charqueadas, however, due to too main factors: the low technological level of that industry imposed that work could be done there only under a severe discipline that was incompatible with a free labor-based organization. Also, the charque producers themselves were culturally attached to the idea of slave labor, that they could not accept the social and legal rules demanded by free workers. In addition, the Platino charque producers had improved their competition power, imposing an increase in the productivity of the Brazlian charque producers.

The neat result of the situation was that the Brazilian charque producers became trapped in a blind alley, because it still hold for them that the cost of enforcement of slave based-production was less than the cost of enforcement of free labor-based production, but: (1) the shortage of the slaves supplies was a definitive condition, and (2) the difficulties they faced to hire free foreign workers.

Antônio Carlos da Rocha Costa Elements for the Agent-Based Modeling of Slavery Systems
ADCAIJ: Advances in Distributed Computing and Artificial Intelligence Journal Regular Issue, Vol. 9 N. 1 (2020), 15-27 eISSN: 2255-2863 - https://adcaij.usal.es Ediciones Universidad de Salamanca - CC BY-NC-ND 
The fall of the slave based-economic system of southern Brazil, centered around the charqueadas, was inevitable, and by the end of the XIX century that industry had virtually disappeared. The legal abolition of slavery, in 1888, came just to put a formal end to it.

\section{Conclusion}

This paper introduced elements for the agent-based modeling of slavery-based economic system. Making use of the formal model of material agent societies, a formal account was given of basic aspects of slavery-based economic systems: chattel slavery, master-slave property relation, master-slave economic exchange, slavery- based economic exchanges, slavery-based economic processes, slavery-based economic system. Basic aspects of slavery-supporting legal systems were also formally presented.

As a first case study, North \& Thomas' model for the rational choice between slavery-based and free labor-based elementary economic systems was shown to be applicable to material agent societies. As a second case study, elements of F. H. Cardoso's study of slavery in the south of Brazil were used to formally characterize aspects of the slave based-charque industry.

\section{References}

Archer, L., 1988. Slavery and Other Forms of of Unfree Labor. Routledge.

Blackburn, R., 1988. Slavery - Its Special Features and Social Role. In Archer, L., editor, Slavery and Other Forms of Unfree Labor. Routledge, London.

Cardoso, F. H., 1997. Capitalismo e Escravidão no Brasil Meridional - O Negro na Sociedade Escravocrata do Rio Grande do Sul. Paz e Terra, Rio de Janeiro.

Costa, A. C. R., 2015. Situated Legal Systems and their Operational Semantics. Artificial Intelligence \& Law, 43(1):43-102.

Costa, A. C. R., 2017a. Ecosystems as Agent Societies, Landscapes as Multi-Societal Agent Systems. In Adamatti, D. F., editor, Multiagent Based Simulations Applied to Biological and Environmental Systems, pages 25-43. IGI Global, Hershey.

Costa, A. C. R., 2017b. Energy Systems in Material Agent Societies. RITA - Revista de Informática Teórica e Aplicada, 24(2):130-144.

Costa, A. C. R., 2017c. TPO and SML - A Societal Type System and a Society Modeling Language for Agent Societies. Technical report, Tutorial presented at WESAAC 2017, São Paulo. Available on https://wesaac.c3.furg.br and on https://sites.google.com/site/foundationsofagentsocieties.

Costa, A. C. R., 2018. Elementary Economic Systems in Material Agent Societies. In Anais do WESAAC 2018, pages 12-24. UECE, Fortaleza.

Costa, A. C. R., 2019. A Variational Basis for the Regulation and Structuration Mechanisms of Agent Societies. Springer, Cham.

Klein, H. S. and Luna, F. V., 2010. Slavery in Brazil. Cambridge University Press, Cambridge.

North, D. C. and Thomas, R. P., 1971. The Rise and Fall of Manorial Systems: A Theoretical Model. The Journal of Economic History, 31(4):777-803.

Wikipedia, 2019. Colonial Brazil. Available at https://en.wikipedia.org/wiki/Colonial_Brazil.

Antônio Carlos da Rocha Costa Elements for the Agent-Based Modeling of Slavery Systems
ADCAIJ: Advances in Distributed Computing and Artificial Intelligence Journal Regular Issue, Vol. 9 N. 1 (2020), 15-27 eISSN: 2255-2863 - https://adcaij.usal.es Ediciones Universidad de Salamanca - CC BY-NC-ND 